\title{
Fraudulent Statements Disclosure And Financial Distress: A Discrete-Time Survival Analysis
}

Yung-I Lou, Nan Hua University, Chiayi, Taiwan

Ming-Long Wang, National Cheng Kung University, Tainan, Taiwan

\begin{abstract}
This study uses discrete-time survival analysis (DTSA) to examine the influence of fraudulent statements disclosure on the probability of financial distress not only in the initial period subsequent to disclosure, but future periods as well. Evidence indicates DTSA is superior to logistic regression and extends a richer depiction of the probability after a first-time fraudulent statement disclosure. After fraudulent statements disclosure, $24 \%$ of the reporting firms experienced financial distress in Year 1, with the hazard function declines progressively in subsequent years. We find total liability to total assets, directors and supervisors' stock pledged ratio, and CPA (Certified Public Accountant) change are definitely linked to financial distress probability (p-value <0.05). A DTSA model not only includes financial ratios, but also considers corporate governance variables to produce more accurate classification than those of alternative models.
\end{abstract}

Keywords: Discrete-Time Survival Analysis, Fraudulent Statements Disclosure, Financial Distress, Corporate Governance

\section{INTRODUCTION}

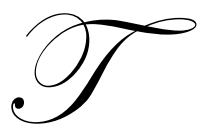

he growing number of financial statements restatements and mounting questions about corporate accounting practices appear to cause investors' confidence in our financial reporting system to be shaky $(\mathrm{GAO}, 2002)^{1}$. Follow the initial restatement announcement, the stock price and earnings response coefficient drop significantly (Andersen and Yohn, 2002; Griffin et al., 2004) while lawsuit and bankruptcy probabilities rise (Palmrose and Scholz, 2004; Palmrose et al., 2004). Among these economic consequences, bankruptcy or financial distress seriously damage stockholder's wealth.

The firm, Securities Exchange Commission (SEC), independent auditor, or a combination thereof can identify a need for restatement. Palmrose et al. (2004) find that the stock price declines sharply if the SEC issues enforcement action (Accounting and Auditing Enforcement Releases; AAER) or if the company's admits to misstatement due to fraud/irregularities, or if the restatement is initiated by auditor. They conjecture that with restatements initiated by an external party, investors question management's integrity, which is likely to increase risk/uncertainty and may well degrade future company prospects. Disclosure of restatements elevates capital cost (Dechow et al., 1996; Hribar et al., 2004). They offer proof of different consequences from voluntary and

\footnotetext{
${ }^{1}$ According to the GAO (2002) report "Financial statement restatements trends, market impacts, regulatory responses, and remaining challenges" (p. 4): “...The number of financial statement restatements identified each year rose from 83 in 1997 to 220 in 2001. The proportion of listed companies on NYSE, Amex, and Nasdaq identified as restating their financial reports tripled from less than 0.89 percent in 1997 to about 2.5 percent in 2001 and may reach almost 3 percent by the end of 2002. From January 1997 through June 2002, about 10 percent of all listed companies announced at least one restatement..." Taiwan is similar to U.S.A.; the average percentage of financial statement restatements (trade in TSE and OTC market) is $2.6 \%$ during 1997 to 2000 (Chen, 2002).
} 
mandatory restatements. Several papers about this issue recently examined SEC accounting enforcement action (Dechow et al., 1996; Griffin et al., 2004). Also, GAO (2002) only focuses on the accounting irregularity defined as the instance in which a company restates its financial statements due to the SEC's address on accounting and auditing irregularities. Palmrose and Scholz (2004) find companies with core restatements showing higher frequencies of fraud, SEC enforcement action, and bankruptcy or delisting. The correlation coefficient between fraud and bankruptcy or delisting is 0.27 (statistically significant). No corresponding study probes correlation between mandatory restatements and subsequent financial distress (or bankruptcy).

This study deals with whether a fraudulent statement announcement can signal financial distress. We want to understand more deeply the impact of a mandatory restatement by the Taiwan Securities and Futures Bureau (TSFB) on financial distress, not only, in an initial period subsequent to disclosure, but also in future periods. For example, though disclosure does not precipitates any failure in the immediate subsequent period, the consequences thereof (higher capital cost, sharper drops in stock price, increased doubts of investor's and banker's etc.) could be accelerating the firm's insolvency in future periods. To conduct our examination, we use discrete-time survival analysis (DTSA) (Cox, 1972) to obtain risk profiles illustrating the impact of the fraudulent statement disclosure on the firm's subsequent existence. We do find that $24 \%$ of the firms that disclose financial statement misstatement failed in the year subsequent to disclosure. Also, the hazard function decreases over time. Total liability to total assets (TLTA), directors and supervisors' stock pledged ratio (Pledge) and CPA change (CPA) markedly raise the likelihood of financial distress. We propose a model using financial ratios and corporate governance variables to yield classifications that provide a more accurate forecast than those of alternative models. Our results demonstrate that DTSA models as more appropriate than single period static models for forecasting financial distress.

Our study represents an extension of prior research in two ways. First, we compare results among baseline hazard, discrete-time survival analysis and simple hazard models. Second, we examine the impact of corporate governance variables on financial distress. The remaining sections of the paper are organized as follows. The next section discusses extant empirical research on financial distress. Subsequent sections introduce discrete-time hazard models, define variables, and describe samples. Empirical findings are then reported and discussed. Finally we present our conclusions.

\section{PRIOR RESEARCH}

Smith and Winkor (1935) first study corporate financial distress using financial ratios. The main statistical method used in earlier studies is univariate analysis, which represents works like Beaver (1966). Altman (1968) first applied the Multiple Discriminant Analysis (MDA) when screening stepwise five financial ratios as predicators mostly for building the Z-score model. Since the forecasting power of Altman's Z-score model descends before firm goes bankrupt (two years before in some cases), Altman, Haldeman and Narayanan (1977) think that time and environmental factors affect the model's predictive power (accuracy). Moreover, the model does not consider risk and size factors. Blum (1974) builds the corporate financial distress framework from the cash flow viewpoint using current profitability and variability indexes. Also, he was the first to include variability indexes in the model.

Martin (1977) established a bank financial distress prediction model with logit regression to treat financial data that did not fit the assumptions of discriminant analysis. After Ohlson's (1980) empirical evidence that logit has better forecasting power, more financial distress predicting models with logit or probit analyses emerged. Collins and Green (1982) examined the assumptions and properties of MDA (Altman, 1968; 1973 used) and quadratic discriminate analysis (QDA) (Altman et al., 1977 used), compared with the forecasting power of the linear probability model (LPM) (Pifer, 1970 used), and the MDA and logistic regression (LOGIT) (Martin, 1977 used). These methods were often applied to forecasting financial distress. The studies find that LOGIT reduces type I errors by one-half in a data set, and also improves forecasts. Tam and Kiang (1992) also find, though a neural-net approach that LOGIT remains the best classifier in terms of fewer type II and total errors over a one-year period and two-year span. 
Similar to LOGIT, DTSA is a dichotomous choice model which assumes that firms face a choice between two alternatives, and that each particular situation relies on specific firms traits. Louwers et al. (1999) utilize DTSA to supply risk profiles illustrating the impact of going-concern disclosure on clients' subsequent continuance and propose that DTSA exhibited a significant refinement over traditional ordinary least squares (OLS) and LOGIT, in that it not only estimates probability, but also the timing of event occurrence. Shumway (2001) argues that DTSA is more appropriate than single- or static multiple-period models when forecasting financial distress. Since firms change over time, prior models produce finance distress biased probabilities and inconsistent estimates of the probabilities they approximate. Most Taiwanese public firms are family controlled with a high degree of ownership concentration, similar to findings in other countries reported by La Porta et al. (1999) and Claessens et al. (2000). In such a concentrated ownership environment, considering financial ratios alone is not enough. We also rate several variables about corporate governance in our model.

\section{DISCRETE-TIME SURVIVAL ANALYSIS}

Most past research forecasting bankruptcy estimated single-period MDA and LOGIT regression models (Altman, 1968; Ohlson, 1980). These failed to account for the amount of time elapsed before event occurrence (Louwers et al., 1999). DTSA can partially alleviate data truncation problems inherent in most LOGIT and OLS studies. Therefore, we employ DTSA (Cox, 1972) to provide the impact of mandatory restatement disclosure on a company's subsequent continuance. Analogous to logistic regression, DTSA is a dichotomous choice model that assumes a firm's choice relies on specific characteristics and distinguishes between firms that fail earlier or later in a sample period. There are three reasons to prefer DTSA in forecasting. First, DTSA considers observations of those firms that did not trigger the event are rightly censored, since endpoints of a sample event horizon are unknown. Second, DTSA incorporates time-varying covariates, explanatory variables changing with time. Third, DTSA can yield more efficiency out-of-sample forecasts (Louwers et al., 1999; Shumway, 2001).

This study's event of interest is financial distress. An obvious starting point is the date of disclosed mandatory restatement. Assuming an observed starting point $(\mathrm{t}=0)$ for each firm $(i=1,2,3 \ldots$.$) , observation$ continues until time $\mathrm{T}=t_{i}$, at which point either an event occurs or an observation is censored. Let $P_{i t}$ be the discrete-time hazard rate or failure rate, then the proportion of failure in each of several successive time periods is given by:

$$
P_{i t}=\operatorname{Pr}\left[T_{i}=t \mid T_{i} \geq t, x_{i t}\right],
$$

where, $\mathrm{T}$ is the discrete random variable giving the uncensored time of event occurrence. $P_{i t}$ is the conditional probability that an event occurs at time $t$, supposing that it has not already occurred. On the other hand, survivor probabilities $\left(S_{i t}\right)$ represent firm $i$ not undergoing financial distress in successive time periods $(t)$ and can be formulated as:

$$
S_{i t}=S_{i t-1}\left(1-P_{i t}\right)
$$

Hazard probability depends on time dummy (D) and explanatory variables (X). The most popular presentation is a logistic regression function (Cox, 1972; Myers et al., 1973; Byar and Mantel, 1975; Brown, 1975; Thompson, 1977; Mantel and Hankey, 1978; Allison, 1982).

$$
P_{i t}=\frac{1}{1+e^{-\left[\left(\alpha_{1} D_{1 i t}+\alpha_{2} D_{2 i t}+\ldots+\alpha_{T} D_{T i t}\right)+\left(\beta_{1} X_{1 i t}+\beta_{2} X_{2 i t}+\ldots+\beta_{T} X_{T i t}\right)\right]}} .
$$

which can be taken as logarithmic transformation of both sides, a simplified form. The LOGIT discrete-time is written:

$$
\ln \left(\frac{P_{i t}}{1-P_{i t}}\right)=\left(\alpha_{1} D_{1 i t}+\alpha_{2} D_{2 i t}+\ldots+\alpha_{T} D_{T i t}\right)+\left(\beta_{1} X_{1 i t}+\beta_{2} X_{2 i t}+\ldots+\beta_{T} X_{T i t}\right) .
$$

where $\left(\mathrm{D}_{1 i t}+\mathrm{D}_{2 i t}+\ldots+\mathrm{D}_{\text {Tit }}\right)$ are a series of time dummy variables, indexing years. The log-odds represent a 
quantity associated with the hazard function in relation to the chance of (non-)failure. The discrete-time model has no single stand-alone intercept; alpha parameters $\left(\alpha_{1}, \alpha_{2}, \ldots \alpha_{T}\right)$ form multiple intercepts, one per time period. Interpretations of slope parameters $\left(\beta_{1}, \beta_{2}, \ldots \beta_{T}\right)$ are similar to those in LOGIT; The slope indicates the effect of a one-unit difference of that predictor on the LOGIT-hazard.

With all covariate values $\mathrm{X}_{T}$, set to zero, the population discrete-time hazard depends only on time dummies $\left(\mathrm{D}_{1}, \mathrm{D}_{2} \ldots \mathrm{D}_{T}\right)$. This model presents population baseline hazard function (Louwers et al., 1999), while a discrete-time hazard model depends only on explanatory variables $\left(\mathrm{X}_{1 i t-1}, \mathrm{X}_{2 i t-1}, \ldots \mathrm{X}_{T i t-1}\right)$, called the simple hazard model (Kiefer, 1988; Lancaster, 1990, Shumway, 2001).

\section{METHODOLOGY}

\section{Dependent Variables}

Before the 1960s, most papers define failure merely as bankruptcy. Beaver (1966) widens the scope: "The firm is said to have failed when any of the following events have occurred: bankruptcy, bond default, an overdrawn bank account, or nonpayment of a preferred stock dividend." Definition of failure (financial distress) is referenced by Beaver (1966), Altman (1968), and Blum (1974). "Failure" is defined in this paper as inability to pay financial obligations as they mature. A firm is said to have failed when any of the following occur: bankruptcy, receivership, reorganization, bond default, an overdrawn bank account, nonpayment of preferred stock dividend, change in trading method to full delivery, and delisting.

\section{Independent Variables}

Most past research forecasting bankruptcy considered financial explanatory variables only. This study also contemplates corporate governance variables and their impact on financial distress. Lee and Yeh (2004) provide empirical evidence that weak corporate governance aggravates probability for financial distress. We decide two dimensions of explanatory variables in this paper. Financial variables considered are mostly derived from a broad class of financial ratios, significant explanatory variables in past financial distress models. We select six variables classified into categories of liquidity (current assets to current liabilities, working capital to total assets), financial leverage (total liabilities to total assets, market value of equity to total assets), and profitability (net income to total assets, retained earnings to total assets). Variables relative to corporate governance included the stock pledge ratio, the chairman of the board also occupying CEO/president positions, auditor change and auditor opinion.

\section{Current Ratio $($ CACL) $(-)=$ Current Assets to Current Liabilities}

The current ratio is an analysis tool for short-term liquidity and solvency. Beaver (1966), Ohlson (1980), Tam and Kiang (1992) include this variable in their models. The predicate sign is negative.

\section{Working Capital to Total Assets (WCTA) (-)}

Working capital to total assets ratio is a measure of the net liquid assets of a firm relative to total capitalization. Liquidity and size are considered aboveboard. Altman (1968) thinks that a firm experiencing consistent operating losses will have shrinking current assets in relation to total assets. Beaver (1966) also includes this variable in his models. The predicate sign is negative.

\section{Liabilities Ratio (TLTA)(-) = Total Liabilities to Total Assets}

Liabilities ratio is common in pervious models (Ohlson, 1980; Zmijewski, 1984; Beaver, 1966; Gombola et al., 1987; Theodossiou et al., 1996) for measuring financial leverage of firms. The predicate sign is negative. 


\section{Market Value Equity to Total Liabilities (MVTL)(-)}

Market value equity to total liabilities shows how much a firm's assets decline in market value before liabilities exceed assets and the firm becomes insolvent (Altman, 1968). The measure's reciprocal present the financial leverage of firms.

\section{Return on Assets (NITA) (-) = Net Income to Total Assets}

Return on invested capital is viewed as financing sources, using debt and equity capital (total assets), to gauge profitability. Models by Beaver (1966), Ohlson (1980), Lo (1986), Gombola et al. (1987) include this variable; predicate sign is negative.

\section{Retained Earnings to Total Assets (RETA)(-)}

Amount of retained earnings depends on long-term profitability and the established age of a firm. In essence, it is a measure of the true productivity of firm's assets (Altman, 1968). Altman (1993) finds $47 \%$ of bankrupt companies' had established ages below five years. We predicate that bad long-term profitability or shorter established years of firms will increase the financial distress probability.

\section{Stock Pledge Ratio (Pledge) (+)}

The value equals directors and supervisors report to the TSFB the percentage of their shareholdings pledged for loans and credits. Since pledging for loans reduces personal funds required, the degree of personal leverage expanded by managerial stockholder creates risk for companies. When the stock market collapses, managerial stockholders have motivation to maintain the stock price (their collateral). If corporate governance is weak, corporate funds represent the easiest and fastest funding for stock price support. Unfortunately, when stock markets continue to fall, companies are trapped in financial difficulties (Lee and Yeh, 2004). We predicate that directors, supervisors, and managers pledging stock with higher rate of firms will increase the financial distress probability.

\section{The Chairman of the Board also occupies CEO/President positions (CEO) (+)}

This is a dummy variable with a value of one if the chairperson of board holds the managerial positions of CEO or president, and zero otherwise. Because a chairman of the board conducts board of director meetings and oversees the process of hiring, evaluation and compensation of the CEO, Jensen (1993) argues for separating chairman and CEO/president positions if a board is to be an effective monitoring device. Predicate sign is positive.

\section{Auditor Change (Change) (+)}

Dummy variable has a value of one for new audit in the two years or less, and zero otherwise. Sorenson $e t$ al. (1983) imply that a client may even change auditors so as to reduce likelihood of detection of a financial statement fraud. Loebbecke et al. (1989) proffer evidence that 36 percent of the fraud in their sample were committed in the initial two years of an auditor's tenure. Risk of audit failure and subsequent litigation is higher during an initial engagement than in subsequent years (Stice, 1991). Both Krishnan and Krishnan (1997) and Shu (2000) find auditor resignation positively associated with the likelihood of litigation. The predicate sign is positive.

\section{Auditor Opinion (OPINION) (+)}

Dummy variable equals one if a firm receives a standard unqualified audit opinion, zero otherwise. If a firm that had fraudulent statements receives a non-standard unqualified audit opinion, it means the financial statements were not presented fairly. This would lead to banks and investors questioning management's integrity, which in turn would lead to financial distress. Predicate sign is positive. 


\section{Sample Selection and Data}

The financial statement fraud sample is limited to publicly traded firms because the study examines information only available in proxy statements and financial statements filed with the SEC (Beasley, 1996). Previous financial statement fraud papers, (the source is the Accounting and Auditing Enforcement Releases (AAERs)), issued by the SEC and the Wall Street journal Index (WSJ index) titled "Crime - White Collar Crime" in U.S. Proxy of financial fraud in our study is a firm subject to accounting enforcement actions (mandatory restatements) by the TSFB, similar to U.S. SEC for alleged violations of Generally Accepted Accounting Principles.

We obtained samples from Taiwanese publicly traded companies, including Taiwan Stock Exchange (TSE) and computerized over-the-counter market (OTC). Samples were also obtained from Taiwan Economic Journal (TEJ) - Taiwan Company profile and information released by TSFB. Other financial and corporate governance information was found in TEJ. Stock pledge ratio was obtained from Info Times Database. Companies identified as ones against which the SEC has taken a mandatory act and which were reported to address accounting and auditing irregularities during 1995-2005. These were 103 in number, of which 27 suffered financial distress prior to occurrence of fraud, 15 belonged to the banking, securities or insurance industry. Two companies had incomplete information. The 59 firms with complete information are included in the sample of firms disclosing fraudulent statements. Table 1 (Panel A) records sample selection procedures, Panel B the distribution of event years.

Table 1: Sample Composition

\begin{tabular}{|c|c|c|c|c|}
\hline \multicolumn{5}{|c|}{ Panel A: Sample Selection } \\
\hline \multicolumn{4}{|c|}{ Initial fraudulent statements disclosure identified, 1995-2005 } & 103 \\
\hline \multicolumn{5}{|c|}{ Less: } \\
\hline \multicolumn{2}{|c|}{ Companies already in financial distress } & \multicolumn{3}{|c|}{27} \\
\hline \multicolumn{2}{|c|}{ Companies belong to banks, securities or insurance firms } & \multicolumn{2}{|r|}{15} & \\
\hline \multicolumn{2}{|c|}{ Companies with incomplete information } & & \multirow[t]{2}{*}{$\underline{2}$} & $(44)$ \\
\hline Total number of $\mathrm{fr}$ & ed in study & & & $\underline{59}$ \\
\hline \multicolumn{5}{|c|}{ Panel B: Distribution of Event Years } \\
\hline Year & $\begin{array}{c}\text { Fraudulent statements } \\
\text { disclosure }\end{array}$ & Financial distress & & No financial distress yet \\
\hline 1995 & 7 & 1 & & 6 \\
\hline 1996 & 8 & 1 & & 13 \\
\hline 1997 & 3 & 0 & & 16 \\
\hline 1998 & 9 & 1 & & 24 \\
\hline 1999 & 7 & 0 & & 31 \\
\hline 2000 & 5 & 8 & & 28 \\
\hline 2001 & 3 & 2 & & 29 \\
\hline 2002 & 3 & 3 & & 29 \\
\hline 2003 & 5 & 1 & & 33 \\
\hline 2004 & 5 & 4 & & 34 \\
\hline 2005 & 4 & 3 & & 35 \\
\hline Total & 59 & 24 & & \\
\hline
\end{tabular}

Panel C contains industry and market classification of samples. Firms were divided by industry except electronics and construction. We use $\chi^{2}$ to test the impact of different industry and trade market on event occurrence. We find phi value between industry of fraudulent firms and financial distress occurrence to be 0.39 ( $p$-value $=0.78$ ). The phi value between fraudulent firm's trading market and event occurrence is 0.128 ( $\mathrm{p}$-value $=0.32$ ). Impact of different industries and trade markets on financial distress is not statistically significant. 
Table 1: Sample Composition (Continued)

\begin{tabular}{|c|c|c|c|c|c|c|c|c|c|c|c|c|}
\hline \multicolumn{13}{|c|}{ Panel C: Industry and Market Classification } \\
\hline \multirow{3}{*}{ Industry } & \multicolumn{6}{|c|}{ Financial distress } & \multicolumn{6}{|c|}{ No financial distress yet } \\
\hline & \multicolumn{2}{|c|}{ TSE } & \multicolumn{2}{|c|}{ OTC } & \multicolumn{2}{|c|}{ Total } & \multicolumn{2}{|c|}{ TSE } & \multicolumn{2}{|c|}{ OTC } & \multicolumn{2}{|c|}{ Total } \\
\hline & $\mathbf{n}$ & $\%$ & $\mathbf{n}$ & $\%$ & $\mathbf{n}$ & $\%$ & $\mathbf{n}$ & $\%$ & $\mathbf{n}$ & $\%$ & n & $\%$ \\
\hline Food & 3 & 12.50 & 0 & 0 & 3 & 12.50 & 0 & 0 & 0 & 0 & 0 & 0 \\
\hline Plastic & 2 & 8.33 & 0 & 0 & 2 & 8.33 & 0 & 0 & 1 & 2.86 & 1 & 2.86 \\
\hline Textile & 1 & 4.17 & 0 & 0 & 1 & 4.17 & 1 & 2.86 & 0 & 0 & 1 & 2.86 \\
\hline Electric machinery & 1 & 4.17 & 0 & 0 & 1 & 4.17 & 4 & 11.43 & 0 & 0 & 4 & 11.43 \\
\hline Electric wire and cable & 1 & 4.17 & 0 & 0 & 1 & 4.17 & 1 & 2.86 & 0 & 0 & 1 & 2.86 \\
\hline Chemicals & 0 & 0 & 1 & 4.17 & 1 & 4.17 & 1 & 2.86 & 0 & 0 & 1 & 2.86 \\
\hline Steel & 0 & 0 & 1 & 4.17 & 1 & 4.17 & 2 & 5.71 & 0 & 0 & 2 & 5.71 \\
\hline Rubber & 1 & 4.17 & 0 & 0 & 1 & 4.17 & 1 & 2.86 & 0 & 0 & 1 & 2.86 \\
\hline Auto & 1 & 4.17 & 0 & 0 & 1 & 4.16 & 1 & 2.86 & 0 & 0 & 1 & 2.86 \\
\hline Electronics & 5 & 20.83 & 3 & 12.50 & 8 & 33.33 & 13 & 37.14 & 2 & 5.71 & 15 & 42.86 \\
\hline Construction & 4 & 16.66 & 0 & 0 & 4 & 16.66 & 4 & 11.43 & 1 & 2.86 & 5 & 14.29 \\
\hline Transport & 0 & 0 & 0 & 0 & 0 & 0 & 1 & 2.86 & 0 & 0 & 1 & 2.85 \\
\hline Tourism & 0 & 0 & 0 & 0 & 0 & 0 & 1 & 2.86 & 0 & 0 & 1 & 2.85 \\
\hline Merchandise & 0 & 0 & 0 & 0 & 0 & 0 & 1 & 2.86 & 0 & 0 & 1 & 2.85 \\
\hline Total & 19 & 79.17 & 5 & 20.83 & 24 & 100.0 & 31 & 88.57 & 4 & 11.43 & 35 & 100.0 \\
\hline
\end{tabular}

Panel D tabulates the number of financially distressed companies in each of the 11 years for an observation total of 301 firm-years. Out of 59 cases, 35 had no financial distress during that period and are considered censored. The fourth column of Panel D gives the number of firms that are at risk of financial distress, the number of right-censored, and the number of survivals in each year. For Year 1, all 59 firms are at risk. In Year 2, the number at risk diminishes by 16 (the number in financial distress plus the number of right-censored in Year 1). Thus, the number risky firms observed is 43 .

Table 1: Sample Composition (Continued)

Panel D: Distribution of Survival Period

\begin{tabular}{ccccc}
\hline Survival period (year) & $\begin{array}{c}\text { Number of financially } \\
\text { distressed companies }\end{array}$ & $\begin{array}{c}\text { No financial distress yet } \\
\text { Number of } \\
\text { right-censored }\end{array}$ & $\begin{array}{c}\text { Number of } \\
\text { survival }\end{array}$ & $\begin{array}{c}\text { Number at risk } \\
\text { (Observation) }\end{array}$ \\
\hline 1 year & 12 & 4 & 43 & 59 \\
2 years & 3 & 1 & 39 & 43 \\
3 years & 0 & 5 & 34 & 39 \\
4 years & 0 & 1 & 33 & 34 \\
5 years & 4 & 2 & 27 & 33 \\
6 years & 3 & 1 & 23 & 27 \\
7 years & 0 & 4 & 19 & 23 \\
8 years & 1 & 7 & 11 & 19 \\
9 years & 1 & 1 & 9 & 11 \\
10 years & 0 & 5 & 4 & 9 \\
11 years & 0 & 4 & 0 & 301 \\
\hline Total & 24 & 35 & 242 \\
\hline
\end{tabular}




\section{RESULTS}

\section{Descriptive Statistics and Univariate Analysis}

Table 2 (Panel A) presents means, medians, standard deviations, maxima, and minima for all observations. Data do not conform to assumed normal distribution; Panel B shows results of Wilcoxon and Median tests. Financially distressed and non- distressed firms differ significantly $(\mathrm{p}<.05)$ in most variables. The size difference was insignificant, indicating both types of firms of similar size. Because most variables are deflated by total assets; the size variable also reveals a muticollinearity problem. Therefore, we exclude size from the model.

Table 2: Descriptive Statistics For Selected Firm Characteristics

\begin{tabular}{|c|c|c|c|c|c|c|c|}
\hline \multicolumn{8}{|c|}{ Panel A: Descriptive } \\
\hline Variables & $\begin{array}{c}\text { Observation } \\
\text { (Firm-year) }\end{array}$ & $\mathbf{N}$ & Mean & Median & STD & Max & Min \\
\hline \multirow[t]{3}{*}{ CACL } & Financial Distress & 24 & 1.76 & 1.12 & 2.52 & 12.21 & 0.35 \\
\hline & No Financial distress yet & 277 & 1.68 & 1.43 & 1.19 & 15.11 & 0.10 \\
\hline & Total Firm-year & 301 & 1.68 & 1.42 & 1.34 & 15.11 & 0.10 \\
\hline \multirow[t]{3}{*}{ WCTA } & Financial Distress & 24 & 0.04 & 0.04 & 0.27 & 0.70 & -0.31 \\
\hline & No Financial distress yet & 277 & 0.12 & 0.15 & 0.16 & 0.53 & -0.36 \\
\hline & Total Firm-year & 301 & 0.12 & 0.14 & 0.17 & 0.70 & -0.36 \\
\hline \multirow[t]{3}{*}{ TLTA } & Financial Distress & 24 & 0.59 & 0.60 & 0.22 & 1.08 & 0.07 \\
\hline & No Financial distress yet & 277 & 0.42 & 0.42 & 0.16 & 0.88 & 0.05 \\
\hline & Total Firm-year & 301 & 0.44 & 0.43 & 0.17 & 1.08 & 0.05 \\
\hline \multirow[t]{3}{*}{ MVTL } & Financial Distress & 24 & 2.45 & 0.91 & 6.28 & 30.76 & 0.08 \\
\hline & No Financial distress yet & 277 & 3.08 & 1.69 & 4.14 & 31.71 & 0.12 \\
\hline & Total Firm-year & 301 & 3.03 & 1.61 & 4.34 & 31.71 & 0.07 \\
\hline \multirow[t]{3}{*}{ NITA } & Financial Distress & 24 & -0.17 & -0.12 & 0.18 & 0.04 & -0.84 \\
\hline & No Financial distress yet & 277 & 0.03 & 0.03 & 0.08 & 0.35 & -0.24 \\
\hline & Total Firm-year & 301 & 0.01 & 0.03 & 0.11 & 0.35 & -0.84 \\
\hline \multirow[t]{3}{*}{ RETA } & Financial Distress & 24 & -0.21 & -0.18 & 0.22 & 0.06 & -0.83 \\
\hline & No Financial distress yet & 277 & 0.05 & 0.07 & 0.14 & 0.37 & -0.59 \\
\hline & Total Firm-year & 301 & 0.03 & 0.06 & 0.16 & 0.37 & -0.83 \\
\hline \multirow[t]{3}{*}{ Pledge } & Financial Distress & 24 & 0.45 & 0.44 & 0.34 & 1 & 0 \\
\hline & No Financial distress yet & 277 & 0.23 & 0.12 & 0.27 & 1 & 0 \\
\hline & Total Firm-year & 301 & 0.25 & 0.14 & 0.28 & 1 & 0 \\
\hline \multirow[t]{3}{*}{ CEO } & Financial Distress & 24 & 0.38 & 0 & 0.49 & 1 & 0 \\
\hline & No Financial distress yet & 277 & 0.24 & 0 & 0.43 & 1 & 0 \\
\hline & Total Firm-year & 301 & 0.25 & 0 & 0.44 & 1 & 0 \\
\hline \multirow[t]{3}{*}{ CPA } & Financial Distress & 24 & 0.33 & 0 & 0.48 & 1 & 0 \\
\hline & No Financial distress yet & 277 & 0.06 & 0 & 0.23 & 1 & 0 \\
\hline & Total Firm-year & 301 & 0.08 & 0 & 0.27 & 1 & 0 \\
\hline \multirow[t]{3}{*}{ Opinion } & Financial Distress & 24 & 0.17 & 0 & 0.38 & 1 & 0 \\
\hline & No Financial distress yet & 277 & 0.45 & 0 & 0.50 & 1 & 0 \\
\hline & Total Firm-year & 301 & 0.43 & 0 & 0.50 & 1 & 0 \\
\hline \multirow[t]{3}{*}{ SIZE } & Financial Distress & 24 & 22.51 & 22.80 & 1.10 & 24.69 & 19.31 \\
\hline & No Financial distress yet & 277 & 22.71 & 22.70 & 0.98 & 25.47 & 20.67 \\
\hline & Total Firm-year & 301 & 22.70 & 22.71 & 0.99 & 25.47 & 19.31 \\
\hline
\end{tabular}


Table 2: Descriptive Statistics For Selected Firm Characteristics (Continued)

\begin{tabular}{|c|c|c|c|c|c|c|}
\hline \multirow[b]{2}{*}{ Variables } & \multicolumn{2}{|c|}{ Wilcoxon } & \multirow[b]{2}{*}{ Z Value } & \multicolumn{2}{|c|}{ Median } & \multirow[b]{2}{*}{ Z Value } \\
\hline & $\begin{array}{c}\text { Financial } \\
\text { distress }\end{array}$ & $\begin{array}{l}\text { No financial } \\
\text { distress yet }\end{array}$ & & $\begin{array}{c}\text { Financial } \\
\text { distress }\end{array}$ & $\begin{array}{c}\text { No financial } \\
\text { distress yet }\end{array}$ & \\
\hline CACL & 111.04 & 154.46 & $-2.34 * *$ & 0.33 & 0.51 & $-1.68 *$ \\
\hline WCTA & 122.00 & 153.51 & $-1.70 *$ & 0.42 & 0.51 & -0.83 \\
\hline TLTA & 221.00 & 144.94 & $4.11 * * *$ & 0.79 & 0.47 & $2.97 * * *$ \\
\hline MVTL & 92.46 & 156.07 & $-3.44 * * *$ & 0.13 & 0.53 & $-3.81 * * *$ \\
\hline NITA & 39.33 & 160.68 & $-6.55 * * *$ & 0.04 & 0.54 & $-4.66 * * *$ \\
\hline RETA & 41.58 & 160.48 & $-6.42 * * *$ & 0.00 & 0.54 & $-5.08 * * *$ \\
\hline Pledge & 201.94 & 146.59 & $3.01 * * *$ & 0.75 & 0.48 & $2.57 * *$ \\
\hline CEO & 169.44 & 149.40 & 1.44 & 0.58 & 0.49 & 1.44 \\
\hline CPA & 189.17 & 147.69 & $4.77 * * *$ & 0.64 & 0.49 & $4.77 * * *$ \\
\hline Opinion & 112.08 & 154.37 & $-2.67 * * *$ & 0.27 & 0.52 & $-2.67 * * *$ \\
\hline SIZE & 144.29 & 151.58 & -0.39 & 0.54 & 0.49 & 0.44 \\
\hline
\end{tabular}

$*, * *, * * *$ Significant at p-value $<.10, .05, .01$, respectively.

$\mathrm{CACL}=$ current assets to current liabilities.

WCTA $=$ (current assets less current liabilities) to total assets.

TLTA $=$ total liabilities to total assets.

MVTA = market value equity to total liabilities.

NITA = net income to total assets

RETA = retained earnings to total assets

Pledge = directors and supervisors report to the TSFB the percentage of their shareholdings that are pledged for loans and credits.

CEO = a dummy variable with a value of one if the chairperson of board holds the managerial positions of CEO or president; other is zero.

CPA = a dummy variable with a value of one if new auditor in the two years or less; other is zero.

Opinion = a dummy variable equal to 1 if a firm's received a standard unqualified audit opinion; other is zero.

SIZE $\quad=\ln$ (total assets).

\section{Survival Function and Hazard Function}

From examining survival and hazard functions, a more precise description of the occurrence of financial distress emerges. Figure 1 (Panel A) illustrates the survival function $S_{i t}=S_{i t-1}\left(1-P_{i t}\right)$. When $t=0$, no firm exhibits financial distress and the survival function equals "one". Over time, the survival function decreases in companies failing continuously. Figure 1 (Panel B) presents a hazard function; hazard rate $\left(P_{i t}\right)$ is conditional probability that an event occurs at time t. We use the square spline to present a smooth curve of hazard occurrence (Beck, Katz and Tucker, 1998). Obviously, a smooth curve of hazard declines over time. In Figure 1 (Panel B), about $24 \%$ of the firms with fraudulent statement disclosure triggered financial distress in the subsequent year. In fact, approximately $50 \%$ of firms in this study are estimated to survive the entire study period. This result is interesting. A large percentage of the firms experience financial distress in Year 1. This means if the misstating firms already had existed financial problem, then subsequent to fraudulent statements disclosure the firms would fall into financial distress. 
Panel A: Survival function

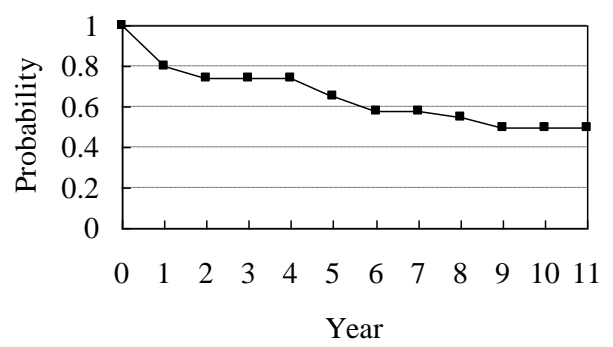

Survival function
Panel B: Hazard function

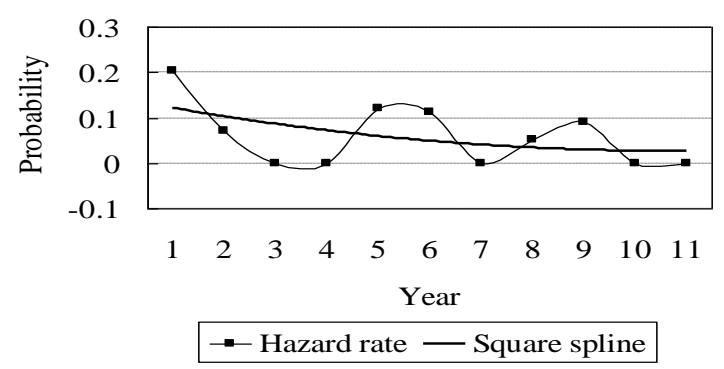

Figure 1: Graphs Of Survival And Hazard Function.

\section{Multivariate Results}

Table 3 presents parameter estimates, $p$-values, and goodness-of-fit statistics for the baseline hazard model. The baseline model is a logistic regression on event occurrence including only time dummies as independent variables. Model 1 includes all time dummy variables, 11 dummies (1995-2005); The Likelihood Ratio is highly significant ( $p<.01$ ). R-square is 0.35 greater than .20 (McFadden, 1974), showing this model's adequacy. Years 3, 4 , 7, 10, and 11 lack financial distress occurrence. So we combine them into a constant: Model 1A. Concordance of Model $1 \mathrm{~A}$ is $83.5 \%$ higher than Model $1 ; \mathrm{R}^{2}$ is only $0.08(<0.2)$ lower than Model 1 . Since Model $1 \mathrm{~A}$ is a simple form of Model 1, we conduct a Likelihood Ratio test that compares models. We obtain $\Delta$ L.R. $=280.03-55.27=$ $224.76>\chi_{0.01,5}^{2}=15.09$ indicating that Model 1 is preferable to Model 1A. Also, the abbreviated dummy variables make a significant $(p<0.01)$ contribution.

Table 3: Results Of Baseline Hazard Model

Model 1: $\ln \left(\frac{P_{i t}}{1-P_{i t}}\right)=\left(\alpha_{1} D_{1 i t}+\alpha_{2} D_{2 i t}+\ldots+\alpha_{T} D_{T i t}\right)$

\begin{tabular}{|c|c|c|c|c|}
\hline \multirow{2}{*}{ Variable } & \multicolumn{2}{|c|}{ Model 1} & \multicolumn{2}{|c|}{ Model 1A } \\
\hline & Parameter estimate & Wald Chi-square & Parameter estimate & Wald Chi-square \\
\hline Intercept & & & -6.12 & $37.44 * * *$ \\
\hline D1 & -1.45 & $18.80 * * *$ & 4.67 & $19.59 * * *$ \\
\hline D2 & -2.59 & $18.72 * * *$ & 3.53 & $9.18 * * *$ \\
\hline D3 & -15.20 & 0.00 & -- & -- \\
\hline D4 & -15.20 & 0.00 & -- & -- \\
\hline D5 & -1.98 & $13.79 * * *$ & 4.14 & $13.35 * * *$ \\
\hline D6 & -2.08 & $11.53 * * *$ & 4.05 & $11.88 * * *$ \\
\hline D7 & -15.20 & 0.00 & -- & -- \\
\hline D8 & -2.89 & $7.91 * * *$ & 3.23 & $5.08 * *$ \\
\hline D9 & -2.30 & $4.82 * *$ & 3.82 & $6.95 * * *$ \\
\hline D10 & -15.20 & 0.00 & -- & -- \\
\hline D11 & -15.20 & 0.00 & -- & -- \\
\hline LR index & \multicolumn{2}{|c|}{$280.03(p<.0001)$} & \multicolumn{2}{|c|}{$55.27(p<.0001)$} \\
\hline Model $\mathrm{R}^{2}$ & \multicolumn{2}{|c|}{0.35} & \multicolumn{2}{|l|}{0.08} \\
\hline Concordant & \multicolumn{2}{|c|}{$32 \%$} & \multicolumn{2}{|c|}{$83.5 \%$} \\
\hline Discordant & \multicolumn{2}{|c|}{$60 \%$} & \multicolumn{2}{|c|}{$7.8 \%$} \\
\hline
\end{tabular}

$*, * *, * * *$ Significant at $\mathrm{p}$-value $<.10, .05, .01$, respectively.

D1-D11 = Time dummy variables representing years subsequent to fraudulent statements disclosure.

Other variables are defined in Table 2. 
Table 4: Results Of Models

Model 1Baseline Hazard Model: $\ln \left(\frac{P_{i t}}{1-P_{i t}}\right)=\left(\alpha_{1} D_{1 i t}+\alpha_{2} D_{2 i t}+\ldots+\alpha_{T} D_{T i t}\right)$

Model 2A Discrete-Time Survival Analysis Model (I):

$$
\ln \left(\frac{P_{i t}}{1-P_{i t}}\right)=\left(\alpha_{1} D_{1 i t}+\alpha_{2} D_{2 i t}+\ldots+\alpha_{T} D_{T i t}\right)+\left(\beta X_{\text {Financial } i t}+\beta X_{\text {CorporateGovernance } i t}\right)
$$

Model 2B Discrete-Time Survival Analysis Model (II):

$$
\ln \left(\frac{P_{i t}}{1-P_{i t}}\right)=\left(\alpha_{1} D_{1 i t}+\alpha_{2} D_{2 i t}+\ldots+\alpha_{T} D_{T i t}\right)+\left(\beta X_{\text {Financial it }}\right)
$$

Model 3A Simple Hazard Model (I): $\ln \left(\frac{P_{i t}}{1-P_{i t}}\right)=\alpha+\left(\beta X_{\text {Financial } i t}+\beta X_{\text {CorporateGovernance } i t}\right)$

\begin{tabular}{|c|c|c|c|c|c|c|c|c|c|c|c|}
\hline \multirow{2}{*}{ Variables } & \multirow{2}{*}{$\begin{array}{l}\text { Exp. } \\
\text { Sign }\end{array}$} & \multicolumn{2}{|c|}{ Baseline Hazard } & \multicolumn{2}{|c|}{ DTSA (I) } & \multicolumn{2}{|c|}{ DTSA (II) } & \multicolumn{2}{|c|}{ Simple Hazard (I) } & \multicolumn{2}{|c|}{ Simple Hazard (II) } \\
\hline & & Coe. $^{a}$ & Wald $\chi^{2}$ & Coe. $^{a}$ & Wald $\chi^{2}$ & Coe. $^{a}$ & Wald $\chi^{2}$ & Coe. $^{a}$ & Wald $\chi^{2}$ & Coe. $^{a}$ & Wald $\chi^{2}$ \\
\hline Intercept & & -- & -- & -- & -- & -- & -- & -8.95 & $21.27^{\text {**⿲丶丶㇒木 }}$ & 1.46 & $28.56^{* \cdots *}$ \\
\hline D1 & - & -1.45 & $18.80^{* * * *}$ & -8.76 & $11.13^{* * *}$ & -6.68 & $11.43^{* * * *}$ & & & & \\
\hline D2 & - & -2.59 & $18.72^{* * * *}$ & -10.06 & $12.80^{* * *}$ & -8.16 & $14.12^{* * *}$ & & & & \\
\hline D3 & - & -15.20 & 0.00 & -21.73 & 0.00 & -20.24 & 0.00 & & & & \\
\hline D4 & - & -15.20 & 0.00 & -22.16 & 0.00 & -20.73 & 0.00 & & & & \\
\hline D5 & - & -1.98 & $13.79^{* * * *}$ & -10.13 & $11.06^{* * *}$ & -7.10 & $11.52^{* * * *}$ & & & & \\
\hline D6 & - & -2.08 & $11.53^{\text {**** }}$ & -7.60 & $8.28^{* * *}$ & -6.48 & $10.09^{* * *}$ & & & & \\
\hline D7 & - & -15.20 & 0.00 & -21.37 & 0.00 & -20.10 & 0.00 & & & & \\
\hline D8 & - & -2.89 & $7.91^{* * *}$ & -9.05 & $12.36^{* * *}$ & -7.84 & $13.71^{* * * *}$ & & & & \\
\hline D9 & - & -2.30 & $4.82^{* *}$ & -7.88 & $7.97^{* * *}$ & -7.02 & $7.78^{* * *}$ & & & & \\
\hline D10 & - & -15.20 & 0.00 & -19.20 & 0.00 & -18.51 & 0.00 & & & & \\
\hline D11 & - & -15.20 & 0.00 & -19.51 & 0.00 & -18.88 & 0.00 & & & & \\
\hline CACL & - & & & 0.52 & 0.20 & 0.71 & 0.55 & 0.61 & 0.42 & 0.63 & 0.66 \\
\hline WCTA & - & & & 3.26 & 0.72 & 2.08 & 0.47 & 3.24 & 0.96 & 2.32 & 0.76 \\
\hline TLTA & + & & & 0.07 & $3.96^{\text {*** }}$ & 0.07 & $4.71^{* * *}$ & 0.06 & $5.89^{* *}$ & 0.07 & $10.26^{* * *}$ \\
\hline MVTL & - & & & -0.12 & 0.07 & -0.23 & 0.37 & -0.13 & 0.10 & -0.16 & 0.27 \\
\hline NITA & - & & & -19.18 & $10.53^{* *}$ & -14.44 & $9.89^{* * * *}$ & -19.18 & $15.14^{* * * *}$ & -15.79 & $14.22^{* * *}$ \\
\hline RETA & - & & & -0.65 & 0.04 & -3.82 & 2.17 & -0.99 & 0.13 & -1.88 & 0.61 \\
\hline PLEDGE & + & & & 2.97 & $4.45^{\text {** }}$ & & & 2.44 & $5.56^{* *}$ & & \\
\hline CEO & + & & & 0.63 & 0.47 & & & 0.23 & 0.10 & & \\
\hline $\mathrm{CPA}$ & + & & & 3.14 & $6.85^{* * *}$ & & & 2.53 & $7.97^{* * * *}$ & & \\
\hline OPINION & - & & & -0.50 & 0.27 & & & -0.79 & 1.06 & & \\
\hline \multicolumn{2}{|c|}{ LR index } & \multicolumn{2}{|c|}{$\begin{array}{c}280.03 \\
(p<.0001)\end{array}$} & \multicolumn{2}{|c|}{$\begin{array}{c}358.95 \\
(p<.0001)\end{array}$} & \multicolumn{2}{|c|}{$\begin{array}{c}344.83 \\
(p<.0001)\end{array}$} & \multicolumn{2}{|c|}{$\begin{array}{c}128.37 \\
(p<.0001)\end{array}$} & \multicolumn{2}{|c|}{$\begin{array}{c}110.98 \\
(p<.0001)\end{array}$} \\
\hline \multicolumn{2}{|c|}{ Model $\mathrm{R}^{2}$} & \multicolumn{2}{|c|}{0.35} & \multicolumn{2}{|c|}{$\begin{array}{r}(p<.0001) \\
0.42\end{array}$} & \multicolumn{2}{|c|}{0.41} & \multicolumn{2}{|c|}{0.18} & \multicolumn{2}{|c|}{0.16} \\
\hline \multicolumn{2}{|c|}{ Concordant } & \multicolumn{2}{|c|}{$32 \%$} & \multicolumn{2}{|c|}{$84.7 \%$} & \multicolumn{2}{|c|}{$75.1 \%$} & \multicolumn{2}{|c|}{$97 \%$} & \multicolumn{2}{|c|}{$96.5 \%$} \\
\hline \multicolumn{2}{|c|}{ Discordant } & \multicolumn{2}{|c|}{$60 \%$} & \multicolumn{2}{|c|}{$15.3 \%$} & \multicolumn{2}{|c|}{$24.8 \%$} & & & & $\%$ \\
\hline$\Delta \mathrm{LR}$ & & & & & $\begin{array}{r}358.95 \\
14.12>\chi\end{array}$ & $\begin{array}{l}344.83 \\
1,4(p<.0\end{array}$ & & & $\begin{array}{c}128.37 \\
17.39>\chi_{0}^{2}\end{array}$ & $\begin{array}{l}110.98 \\
.01,4 \\
(p<.0\end{array}$ & \\
\hline
\end{tabular}

Model 3B Simple Hazard Model (II): $\ln \left(\frac{P_{i t}}{1-P_{i t}}\right)=\alpha+\left(\beta X_{\text {Financial } i t}\right)$

${ }^{*},{ }^{* *},{ }^{* * * *}$ Significant at $\mathrm{p}$-value $<.10, .05, .01$, respectively.

a. The coefficient of estimated of the model.

D1-D11 = Time dummy variables representing years subsequent to fraudulent statements disclosure.

Other variables are defined in Table 2.

Table 4 depicts results of the baseline hazard, discrete-time survival analysis, and simple hazard models. For greater explanatory power, we add financial and corporate governance variables to baseline hazard: i.e., DTSA (I). Coefficient estimates for total liability to total assets (TLTA), directors and supervisors' stock pledged ratio 
(Pledge) and CPA change $(C P A)$ change significantly, positively correlated to financial distress ( $p$-value $<0.05)$. Net income to total assets (NITA) shows strong negative correlation to any incidence of financial distress $(p$-value $<0.05)$. Model 3, the simple hazard model is restricted to $\alpha_{\mathrm{t}}=\alpha$ not considering the time dummy variable. The coefficient estimate of Model 3 is similar to that of Model 2.

To understand the contribution of corporate governance variables, we compare Model 2A with 2B and 3A with 3B. We find the model including corporate governance variables to be better than one only having financial variables. This finding is consistent across all kinds of model indexes. The Likelihood Ratio test also proves Model 2A (3A) to be superior to Model 2B (3B) in statistical significance (0.01). This finding supports the concept that corporate governance variables add more explanatory power to the models. As for valuation among various models, the concordant index of simple hazard (I) is the highest among these models. But we notice that the simple hazard (I) model's $\mathrm{R}^{2}$ is lower than 0.2 , which is below the requirement. Instead, the DTSA (I) is the best model in terms of the LR index and model $\mathrm{R}^{2}$. While the simple hazard (I) is the simple form of DTSA (I). We also conducted the Likelihood Ratio test to compare these two models to obtain $\Delta$ L.R. $=358.95-128.37=230.58>\chi_{0.01,10}^{2}$. Therefore, the resulting DTSA (I) is better than the simple hazard (I) model and we selected it as the best model.

\section{Classification Accuracy Test}

This paper is limited in a few financial distress samples. We apply the Jackknife method instead of the holdout sample forecasting test to forecast classification accuracy. The Jackknife method attempts to examine result replicability without reconducting the same study with a new sample (Crask and Perreault, 1977; Tukey, 1958). It was commonly used for clinical research that lacked enough data. In this method, sometimes called the "leave-one-out" method, one observation is removed and the rule repeated many times to determine the frequency with which the excluded one is misclassified. Use of the Jackknife approach has been demonstrated to produce more conservative and less biased estimates of true population chacteristics (Crask and Perreault, 1977).

Table 5: Classification Accuracy By Jackknife Method

\begin{tabular}{|c|c|c|c|c|c|c|c|c|c|c|}
\hline \multirow{2}{*}{ Hazard Rate } & \multicolumn{2}{|c|}{ Baseline Hazard } & \multicolumn{2}{|c|}{ DTSA (I) } & \multicolumn{2}{|c|}{ DTSA (II) } & \multicolumn{2}{|c|}{ Simple Hazard (I) } & \multicolumn{2}{|c|}{ Simple Hazard (II) } \\
\hline & FD $^{\mathbf{a}}$ & NFD $^{\mathbf{b}}$ & FD $^{\mathbf{a}}$ & NFD $^{\mathbf{b}}$ & FD $^{\mathbf{a}}$ & NFD $^{\mathbf{b}}$ & FD $^{\mathbf{a}}$ & NFD $^{\mathbf{b}}$ & FD $^{\mathbf{a}}$ & NFD $^{\mathbf{b}}$ \\
\hline $\begin{array}{l}\text { Very low risk } \\
\text { group }(<0.01)\end{array}$ & $\begin{array}{c}0 \\
(0.0 \%)\end{array}$ & $\begin{array}{c}109 \\
(39.4 \%)\end{array}$ & $\begin{array}{c}2 \\
(8.3 \%)\end{array}$ & $\begin{array}{c}208 \\
(75.0 \%)\end{array}$ & $\begin{array}{c}1 \\
(4.2 \%)\end{array}$ & $\begin{array}{c}181 \\
(65.3 \%)\end{array}$ & $\begin{array}{c}3 \\
(12.4 \%)\end{array}$ & $\begin{array}{c}179 \\
(64.6 \%)\end{array}$ & $\begin{array}{c}1 \\
(4.2 \%)\end{array}$ & $\begin{array}{c}121 \\
(43.7 \%)\end{array}$ \\
\hline $\begin{array}{l}\text { Low risk } \\
\text { group } \\
(0.01-0.05)\end{array}$ & $\begin{array}{c}2 \\
(8.3 \%)\end{array}$ & $\begin{array}{c}0 \\
(0.0 \%)\end{array}$ & $\begin{array}{c}1 \\
(4.2 \%)\end{array}$ & $\begin{array}{c}29 \\
(10.5 \%)\end{array}$ & $\begin{array}{c}0 \\
(0.0 \%)\end{array}$ & $\begin{array}{c}50 \\
(18.1 \%)\end{array}$ & $\begin{array}{c}1 \\
(4.2 \%)\end{array}$ & $\begin{array}{c}49 \\
(17.7 \%)\end{array}$ & $\begin{array}{c}3 \\
(12.5 \%)\end{array}$ & $\begin{array}{c}95 \\
(34.3 \%)\end{array}$ \\
\hline $\begin{array}{l}\text { Middle risk } \\
\text { group } \\
(0.05-0.10)\end{array}$ & $\begin{array}{c}10 \\
(41.7 \%)\end{array}$ & $\begin{array}{c}58 \\
(20.9 \%)\end{array}$ & $\begin{array}{c}2 \\
(8.3 \%)\end{array}$ & $\begin{array}{c}14 \\
(5.1 \%)\end{array}$ & $\begin{array}{c}5 \\
(20.8 \%)\end{array}$ & $\begin{array}{c}14 \\
(5.0 \%)\end{array}$ & $\begin{array}{c}1 \\
(4.2 \%)\end{array}$ & $\begin{array}{c}13 \\
(4.7 \%)\end{array}$ & $\begin{array}{c}2 \\
(8.3 \%)\end{array}$ & $\begin{array}{c}24 \\
(8.7 \%)\end{array}$ \\
\hline $\begin{array}{l}\text { High risk } \\
\text { group } \\
(0.10-0.20)\end{array}$ & $\begin{array}{c}11 \\
(45.8 \%)\end{array}$ & $\begin{array}{c}110 \\
(39.7 \%)\end{array}$ & $\begin{array}{c}0 \\
(0.0 \%)\end{array}$ & $\begin{array}{c}9 \\
(3.2 \%)\end{array}$ & $\begin{array}{c}1 \\
(4.2 \%)\end{array}$ & $\begin{array}{c}13 \\
(4.7 \%)\end{array}$ & $\begin{array}{c}1 \\
(4.2 \%)\end{array}$ & $\begin{array}{c}20 \\
(7.2 \%)\end{array}$ & $\begin{array}{c}3 \\
(12.5 \%)\end{array}$ & $\begin{array}{c}20 \\
(7.2 \%)\end{array}$ \\
\hline $\begin{array}{l}\text { Very high risk } \\
\text { group }(>0.20)\end{array}$ & $\begin{array}{c}1 \\
(4.2 \%)\end{array}$ & $\begin{array}{c}0 \\
(0.0 \%)\end{array}$ & $\begin{array}{c}19 \\
(79.2 \%)\end{array}$ & $\begin{array}{c}17 \\
(6.1 \%)\end{array}$ & $\begin{array}{c}17 \\
(70.8 \%)\end{array}$ & $\begin{array}{c}19 \\
(6.9 \%)\end{array}$ & $\begin{array}{c}18 \\
(75.0 \%)\end{array}$ & $\begin{array}{c}16 \\
(5.8 \%)\end{array}$ & $\begin{array}{c}15 \\
(62.5 \%)\end{array}$ & $\begin{array}{c}17 \\
(6.1 \%)\end{array}$ \\
\hline Total & $\begin{array}{c}24 \\
(100 \%)\end{array}$ & $\begin{array}{c}277 \\
(100 \%)\end{array}$ & $\begin{array}{c}24 \\
(100 \%)\end{array}$ & $\begin{array}{c}277 \\
(100 \%)\end{array}$ & $\begin{array}{c}24 \\
(100 \%)\end{array}$ & $\begin{array}{c}277 \\
(100 \%)\end{array}$ & $\begin{array}{c}24 \\
(100 \%)\end{array}$ & $\begin{array}{c}277 \\
(100 \%)\end{array}$ & $\begin{array}{c}24 \\
(100 \%)\end{array}$ & $\begin{array}{c}277 \\
(100 \%)\end{array}$ \\
\hline
\end{tabular}

a. Number and percentage of financially distress firms that were correctly classed in the different risk groups.

b. Number and percentage of non financially distress firms that were correctly classed in the different risk groups.

In Table 5 we report the classification accuracy using the Jackknife method for our various models. The 
301 observations (firm-years) are divided into five groups according to hazard rate, "very low risk group", "low risk group", "middle risk group", "high risk group" and "very high risk group". We find classification accuracy of DTSA (I) to be the best among these models. The percentage of financially distress firms that were correctly classed in the very high risk group is $79.2 \%$ and that of non-distressed ones correctly classified as very low risk is $75 \%$. If we combine very high/low risk with high/low risk group, then the classification accuracy ratio of the financially distressed (versus non-distressed) firms is $79.2 \%(85.5 \%)$.

\section{DTSA Model Compare with LOGIT Model}

This section compares the DTSA selected model with LOGIT. Since the model is single period, we estimate via last observation of each firm: i.e., total observations of 59 firms (Table 6). Model 1A is derived from Model 1B, combined with corporate governance variables. Its indexes are notably better. The logistic regression Model 1A is presented by the equation:

$\operatorname{Pr}($ Financial distress $=1)=-10.33+0.14 \mathrm{CACL}+6.03 \mathrm{WCTA}+11.67 \mathrm{TLTA}+0.51 \mathrm{MVTL}-9.07 \mathrm{NIT}$ A $-6.85 \mathrm{RETA}+$

$$
\text { 4.00 PLEDGE + } 0.85 \mathrm{CEO}+1.06 \mathrm{CPA}+0.27 \text { OPINION }
$$

where, the dependent variable equals one if financial distress is present, zero otherwise. Other independent variables are as depicted above. Only two, TLTA and Pledge, coefficients are positive and statistically significant $(p<0.1)$. Contrasted with DTSA (I), the LOGIT Model 1A fits will. The model $\mathrm{R}^{2}$ equals 0.57 , a concordance rate above $95 \%$. These indexes exhibit preferable fitness of LOGIT Model 1A. We then rate classification accuracy of DTSA (I) and LOGIT Model 1 A using the Jackknife method.

Table 6: Results Of Logit Model

\begin{tabular}{|c|c|c|c|c|}
\hline \\
\hline $\ln \left(\frac{P_{i t}}{1-P_{i}}\right)=\alpha+\beta_{1}$ & $\mathrm{CTA}+\beta_{3} \mathrm{TLTA}+\beta_{4} \mathrm{MVTL}+\rho$ & $\mathrm{TA}+\beta_{6} \mathrm{RET} \mathrm{A}+\beta_{7}$ PLEDG & $\mathrm{O}+\beta_{9} \mathrm{CPA}+\beta_{10} \mathrm{OPINION}$ & \\
\hline \multirow{2}{*}{ Variable } & \multicolumn{2}{|c|}{ Model 1A } & \multicolumn{2}{|c|}{ Model 1B } \\
\hline & Parameter estimate & Wald Chi-square & Wald Chi-square & $p$-value \\
\hline Intercept & -10.33 & $5.34 * *$ & -7.20 & $4.93 * *$ \\
\hline CACL & 0.14 & 0.02 & -0.17 & 0.03 \\
\hline WCTA & 6.03 & 1.36 & 4.71 & 1.59 \\
\hline TLTA & 11.67 & $3.65 * *$ & 9.91 & $4.55^{* *}$ \\
\hline MVTL & 0.51 & 2.13 & 0.45 & 2.00 \\
\hline NITA & -9.07 & 0.62 & -5.77 & 0.43 \\
\hline RETA & -6.85 & 0.49 & -9.10 & 1.60 \\
\hline PLEDGE & 4.00 & $3.39^{*}$ & -- & -- \\
\hline CEO & 0.85 & 0.30 & -- & -- \\
\hline CPA & 1.06 & 0.52 & -- & -- \\
\hline OPINION & 0.27 & 0.04 & -- & -- \\
\hline LR index & \multicolumn{2}{|c|}{$49.38(p<.0001)$} & \multicolumn{2}{|c|}{$40.43(p<.0001)$} \\
\hline Model $\mathrm{R}^{2}$ & \multicolumn{2}{|c|}{0.57} & \multicolumn{2}{|c|}{0.50} \\
\hline Concordant & \multicolumn{2}{|c|}{$95.4 \%$} & \multicolumn{2}{|c|}{$93.1 \%$} \\
\hline Discordant & \multicolumn{2}{|c|}{$4.6 \%$} & \multicolumn{2}{|c|}{$6.8 \%$} \\
\hline
\end{tabular}

$*, * *, * * *$ Significant at p-value $<.10, .05, .01$, respectively.

Other variables are defined in Table 2.

The results of classification accuracy using the Jackknife method appear in Table 7. While the percentage of financial distress firms correctly classed as very high risk group is $87.5 \%$, the classification accuracy of a LOGIT model for non financial distressed firms is very low (only 20\%). Clearly, if the evaluation of the model only relies 
on these statistic indexes (i.e. LR, $\mathrm{R}^{2}$ and concordant), then the judgment of a model will be biased. Usually, a LOGIT model has more frequent type I errors. It was quite obvious that the DTSA model is preferable classification accuracy over the LOGIT model.

Table 7: Risk classification table by Jackknife Method

\begin{tabular}{|c|c|c|c|c|}
\hline \multirow[t]{2}{*}{ Hazard rate } & \multicolumn{2}{|c|}{$\begin{array}{c}\text { DTSA (I) } \\
\text { (n: 301 Firm-Years) }\end{array}$} & \multicolumn{2}{|c|}{$\begin{array}{c}\text { LOGIT } \\
\text { (n: 59 Firms) } \\
\end{array}$} \\
\hline & Financial distress & No financial distress yet & Financial distress & Non financial distress \\
\hline $\begin{array}{l}\text { Very low risk group } \\
(\quad<0.01)\end{array}$ & $2(8.3 \%)$ & $208(75.0 \%)$ & $1(4.2 \%)$ & $7(20.0 \%)$ \\
\hline $\begin{array}{l}\text { Low risk group } \\
(0.01-0.05)\end{array}$ & $1(4.2 \%)$ & $29(10.5 \%)$ & $2(8.3 \%)$ & $8(22.9 \%)$ \\
\hline $\begin{array}{l}\text { Middle risk group } \\
(0.05-0.10)\end{array}$ & $2(8.3 \%)$ & $14(5.1 \%)$ & $0(0.0 \%)$ & $7(20.0 \%)$ \\
\hline $\begin{array}{l}\text { High risk group } \\
(0.10-0.20)\end{array}$ & $0(0.0 \%)$ & $9(3.2 \%)$ & $0(0.0 \%)$ & $2(5.7 \%)$ \\
\hline $\begin{array}{l}\text { Very high risk group } \\
\left(\begin{array}{l}>0.20) \\
\end{array}\right.\end{array}$ & $19(79.2 \%)$ & $17(6.1 \%)$ & $21(87.5 \%)$ & $11(31.4 \%)$ \\
\hline Total & $24(100 \%)$ & $277(100 \%)$ & $24(100 \%)$ & $35(100 \%)$ \\
\hline
\end{tabular}

\section{CONCLUSIONS}

This study provides new evidence regarding the influence of fraudulent statements disclosure on the probability of financial distress, not only in the initial period subsequent to disclosure, but in future periods as well. By using discrete-time survival analysis, we develop a hazard model to forecast financial distress. The DTSA is theoretically superior to previous static models. It corrects for period at risk and allows for time-varying covariates. It uses all period data to yield financial distress probability estimates for all firms at each point in time, and thus avoids the selection biases inherent in single period models. DTSA provides a more comprehensive perspective, indicating that $24 \%$ of firms that disclosed financial statement misstatements failed in the subsequent year, and the survival function wanes over time. This paper uses discrete-time survival analysis to evaluate the link between fraudulent statement disclosures and financial distress. Past research in forecasting financial distress mostly gauges financial explanatory variables. This study weighs corporate governance variables versus financial distress probability. The variables included stock pledge ratio, board chairman also occupying CEO/president positions, auditor change and auditor opinion; all contribute additional explanation. After estimating baseline hazard, DTSA, and simple hazard models on a dataset of financial distress observed in firms after fraudulent statement disclosures over 11 years in Taiwan, we found the DTSA model to be most appropriate in terms of classification accuracy using the Jackknife method. The coefficient estimates for total liability to total assets (TLTA), net income to total assets (NITA), directors and supervisors' stock pledged ratio (Pledge) and CPA change (CPA) correlate strongly with financial distress $(p$-value $<0.05$ ). As for DTSA versus single period LOGIT, the classification accuracy is consistent with Shumway (2001) and supports the assertion that hazard models are more appropriate than single period models in forecasting bankruptcy.

\section{REFERENCES}

1. Allison, P., "Discrete-Time Methods for the Analysis of Event Histories," Sociological Methodology, 13, 61-98, 1982.

2. Altman, E.I., "Financial Ratios, Discriminant Analysis, and the Prediction of Corporate Bankruptcy," Journal of Finance, 23 (4), 589-609, 1968).

3. Altman, E.I., G.G. Haldeman, and P. Narayanan, "Zeta Analysis: A New Model to Identify the Bankruptcy Risk of Corporations," Journal of Banking and Finance, 1, 29-54, 1977. 
4. Altman, E.I., G.V. Marco, and F. Varetto, “Corporate Distress Diagnosis: Comparisons Using Linear Discriminant Analysis and Neural Networks (the Italian Experience)," Journal of Banking and Finance, 18(3), 505-529, 1994.

5. Beaver, W., "Financial Ratios as Predictors of Failure, Empirical Research in Accounting: Selected Studies," Journal of Accounting Research, 4(3), 71-111, 1966.

6. Beaver, W., "Market Price, Financial Ratios, and the Prediction of Failure," Journal of Accounting Research, 6(2), 179-192, 1968.

7. Beck, N., J. Katz, and R. Tucker, "Taking Time Seriously: Time-Series-Cross-Section Analysis with a Binary Dependent Variable,” American Journal of Political Science, 42(4), 1260-1288, 1998.

8. Blum, M., "Failing Company Discriminant Analysis," Journal of Accounting Research, 12(1), 1-25, 1974.

9. Brown, C.C., "On the Use of Indicator Variables for Studying the Time Dependence of Parameters in a Response-Time Model,” Biometrics, 31(4), 863-872, 1975.

10. Byar, D.P. and N. Mantel, "Some Interrelationships Among the Regression Coefficient Estimates Arising in a Class of Models Appropriate to Response-Time Data," Biometrics, 31(4), 943-947, 1975.

11. Chen, H.L., "Financial Statement Credibility and Auditing Quality with the Financial Statement Restatement Side - one of the Financial Transparency Estimate," Money Watching and Credit Rating, 37, 77-86, 2002 (in Chinese).

12. Coats, P.K., and L.F. Fant, "Recognizing Financial Distress Patterns Using a Neural Network Tool," Financial Management, 22(3), 142-155, 1993.

13. Cox, D., "Regression Models and Life-Table," Journal of the Royal Statistical Society, 34(2), 187-200, 1972.

14. Crask, M.R., and W.D. Jr. Perreault, "Validation of Discriminant Analysis in Marketing Research," Journal of Marketing Research, 14(1), 60-68, 1977.

15. Deakin, E.B., “A Discriminant Analysis of Predictors of Business Failure,” Journal of Accounting Research, 10(1), 167-179, 1972.

16. Dechow, P.M., R.G. Sloan, and A.P. Sweeney, "Causes and Consequences of Earnings Manipulation: An Analysis of Firms Subject to Enforcement Actions by the SEC," Contemporary Accounting Research, 13(1), 1-36, 1996.

17. General Accounting Office, Financial Statement Restatements: Trends, Market Impacts, Regulatory Responses, and Remaining Challenges, GAO-03-138. (2002)

18. Gombola, M.J., M.E.J. Haskins, E. Keta, and D. Williams, "Cash Flow in Bankruptcy Prediction," Financial Management, 16(4), 55-65, 1987.

19. Griffin, P.A., J. Grundfest, and M.A. Perino, "Stock Price Response to News of Securities Fraud Litigation: An Analysis Sequential and Conditional Information,” Abacus, 40(1), 21-48, 2004.

20. Hribar, P. and N.T. Jenkins, "The Effect of Accounting Restatements on Earnings Revisions and the Estimated Cost of Capital," Review of Accounting Studies, 9(2-3), 337-356, 2004.

21. Jensen, M.C., "The Modern Industrial Revolution, Exit, and the Failure of Internal Control Systems," Journal of Finance, 48(3), 831-880, 1993.

22. Kiefer, N.M., "Economic Duration Data and Hazard Functions," Journal of Economic Literature, 26(2), 646-679, 1988.

23. Koh, H., "Model Predictions and Auditor Assessments of Going Concern Status," Accounting and Business, 21, 331-338, 1991.

24. Krishnan, J. and J. Krishnan, "Litigation Risk and Auditor Resignations," The Accounting Review, 72(4), 539-560, 1997.

25. La Porta, R., F. Lopez-de-Silanes, and A. Shleifer, "Corporate Ownership Around the World," Journal of Finance, 54(2), 471-517, 1999.

26. La Porta, R., F. Lopez-de-Silanes, A. Shleifer, and R.W. Vishny, "Investor Protection and Corporate Valuation," Journal of Finance, 57(3), 1147-1171, 2002.

27. Lancaster, T., The Econometric Analysis of Transition Data. New York: Cambridge University Press, 1990.

28. Lau, A., “A Five-State Financial Distress Prediction Model,” Journal of Accounting Research, 25(1), 127-138, 1987. 
29. Lee, T.S. and Y.H. Yeh, "Corporate Governance and Financial Distress: Evidence from Taiwan," Corporate Governance, 2(3), 378-388, 2004.

30. Lo, A.W., "Logit versus Discriminant Analysis - A Specification Test and Application to Corporate Bankruptcies," Journal Econometrics, 31(2), 151-178, 1986.

31. Loebbecke, J.K., M.M. Eining, and J.J. Willingham, "Auditors' Experience with Material Irregularities: Frequency, Nature, and Detectability," Auditing: A Journal of Practice \& Theory, 9(1), 1-28, 1989.

32. Louwers, T.J., F.M. Messina, and M.D. Richard, "The Auditor's Going-Concern Disclosure as a Self-Fulfilling Prophecy: A Discrete-Time Survival Analysis,” Decision Science, 30(3), 805-824, 1999.

33. Mantel, N. and B. Hankey, "A Logistic Regression Analysis of Response-Time Data where the Hazard Function Is Time Dependent,” Communications in statistics-Theory and Methods, A7, 333-347, 1978.

34. McFadden, D., Conditional Logit Analysis of Qualitative Choice Behavior, Frontiers in Econometrics New York: Academic Press, 105-142, 1974.

35. Myers, M.H., B.F. Hankey, and N. Mantel, “A Logistic-Exponential Model for Use with Response-Time Data Involving Regressor variables,” Biometrics, 29(2), 257-269, 1973.

36. Ohlson, J., "Financial Ratios and the Probabilistic Prediction of Bbankruptcy," Journal of Accounting Research, 18(1), 109-131, 1980.

37. Palmrose, Z-V., V. Richardson, and S. Scholz, "Determinants of Market Reactions to Restatement Announcements," Journal of Accounting and Economics, 37(1), 59-89, 2004.

38. Palmrose, Z.V., S.W. Scholz, "The Circumstances and Legal Consequences of Non-GAAP Reporting: Evidence from Restatements," Contemporary Accounting Research, 21(1), 139-178, 2004.

39. Shu, S., "Auditor Resignations: Clientele Effects and Legal Liability," Journal of Accounting and Economics, 29(2), 173-205, 2000.

40. Shumway, T., "Forecasting Bankruptcy More Accurately: A Simple Hazard Model," Journal of Business, 74(1), 101-124, 2001.

41. Smith, R.F. and A.H. Winkor, "A Test Analysis of Unsuccessful Industrial Companies," University of Illinois of Bureau of Business Research Bulletin, 31, 1930.

42. Smith, R.F. and A.H. Winko, "Change in Financial Structure of Unsuccessful Industrial Corporations," University of Illinois, Bureau of Business Research Bulletin, 51, 1935.

43. Stice, J., "Using Financial and Market Information to Identify Pre-Engagement Factors Associated with Lawsuits Against Auditors," The Accounting Review, 66(3), 516-533, 1991.

44. Sorenson, J.E., H.D. Grove, and F.H. Selto, "Detecting Management Fraud: An Empirical Approach," Symposium on Auditing Research, 5, 73-116, 1983.

45. Tam, K. and M. Kiang, "Managerial Applications of Neural Networks: the Case of Bank Failure Predictions," Management Science, 38(7), 926-947, 1992.

46. Theodossiou, P., E. Kahya, G.C. Philippatos, and R. Saidi, "Financial Distress Corporate Acquisitions: Further Empirical Evidence,” Journal of Business Finance and Accounting, 23(5-6), 699-719, 1996.

47. Thompson, W.A. Jr., "On the Treatment of Grouped Observations in Life Studies," Biometrics, 33(3), 463-470, 1977.

48. Tukey, J.W., "Bias and Confidence in Not-Quite Large Samples," Annals of Mathematical Statistics, 29(2), 614, 1958.

49. Zmijewski, M., "Methodological Issues Related to the Estimation of Financial Distress Prediction Models," Journal of Accounting Research, 22(supplement), 59-82, 1984. 